\title{
Lead accumulation and tolerance of Moso bamboo (Phyllostachys pubescens) seedlings: applications of phytoremediation*
}

\author{
Dan LIU ${ }^{\dagger 1}$, Song LI ${ }^{1}$, Ejazul ISLAM ${ }^{2}$, Jun-ren CHEN $^{1}$, Jia-sen WU ${ }^{1}$, Zheng-qian YE ${ }^{1}$, \\ Dan-li PENG ${ }^{1}$, Wen-bo YAN ${ }^{1}$, Kou-ping LU ${ }^{1}$ \\ $\left({ }^{I}\right.$ Key Laboratory of Soil Contamination Bioremediation of Zhejiang Province, School of Environmental and Resource Sciences, \\ Zhejiang A \& F University, Lin'an 311300, China) \\ ( ${ }^{2}$ National Institute for Biotechnology and Genetic Engineering (NIBGE), Faisalabad 38000, Pakistan) \\ ${ }^{\dagger}$ E-mail: liudan7812@aliyun.com \\ Received Apr. 18, 2014; Revision accepted Sept. 17, 2014; Crosschecked Jan. 7, 2015
}

\begin{abstract}
A hydroponics experiment was aimed at identifying the lead $(\mathrm{Pb})$ tolerance and phytoremediation potential of Moso bamboo (Phyllostachys pubescens) seedlings grown under different $\mathrm{Pb}$ treatments. Experimental results indicated that at the highest $\mathrm{Pb}$ concentration $(400 \mu \mathrm{mol} / \mathrm{L})$, the growth of bamboo seedlings was inhibited and $\mathrm{Pb}$ concentrations in leaves, stems, and roots reached the maximum of $148.8,482.2$, and $4282.8 \mathrm{mg} / \mathrm{kg}$, respectively. Scanning electron microscopy revealed that the excessive $\mathrm{Pb}$ caused decreased stomatal opening, formation of abundant inclusions in roots, and just a few inclusions in stems. The ultrastructural analysis using transmission electron microscopy revealed that the addition of excessive $\mathrm{Pb}$ caused abnormally shaped chloroplasts, disappearance of endoplasmic reticulum, shrinkage of nucleus and nucleolus, and loss of thylakoid membranes. Although ultrastructural analysis revealed some internal damage, even the plants exposed to $400 \mu \mathrm{mol} / \mathrm{L} \mathrm{Pb}$ survived and no visual Pb toxicity symptoms such as necrosis and chlorosis were observed in these plants. Even at the highest Pb treatment, no significant difference was observed for the dry weight of stem compared with controls. It is suggested that use of Moso bamboo as an experimental material provides a new perspective for remediation of heavy metal contaminated soil owing to its high metal tolerance and greater biomass.
\end{abstract}

Key words: Moso bamboo, Pb, Phytoremediation, Scanning electron microscopy, Transmission electron microscopy doi: 10.1631 jzus.B1400107

Document code: A

CLC number: X173

\section{Introduction}

Among heavy metals, lead $(\mathrm{Pb})$ has been acknowledged one of the most abundant metal pollutants in the environment (Patra et al., 2004). Severe $\mathrm{Pb}$ contamination may lead to various environmental problems, such as reduced vegetation structure and biodiversity as well as ground water contamination (Ruley et al., 2006). $\mathrm{Pb}$ is extremely toxic to plants

\footnotetext{
* Project supported by the National Natural Science Foundation of China (No. 31300520), the Science and Technology Program of Zhejiang Province (No. 2014C33043), and the Zhejiang Provincial Natural Science Foundation of China (No. LY12C16004) (10) ORCID: Dan LIU, http://orcid.org/0000-0003-1102-6639 (C) Zhejiang University and Springer-Verlag Berlin Heidelberg 2015
}

and humans, leading to brain damage and retardation (Cho-Ruk et al., 2006; Islam et al., 2007).

Phytoremediation can remove heavy metals using plants and offer the benefits of low cost, as well as being an environmentally sustainable technique. To date, about 700 species of plants have been reported to be hyperaccumulators of different contaminants (Xi et al., 2010). Metal hyperaccumulators are found in a large number of plant families, but most are the Brassicaceae family (Verbruggen et al., 2009; Krämer, 2010). Moreover, hyperaccumulators (e.g., Thlaspi sp.) are associated with slow plant growth and low biomass yields (Tandy et al., 2006; Epelde et al., 2008), so there is an urgent need for identification of other plant species having fast growth and greater 
biomass production. Phytoremediation would be ideal for the recovery of various types of contaminated soil since it is effective and environmentally friendly.

Moso bamboo (Phyllostachys pubescens) grows on more than 3.37 Mha in China, and occupies $70 \%$ of the total bamboo in the country (Chen et al., 2009). Compared with other bamboo species, Moso bamboo has some superior attributes in terms of adaptation to environmental conditions, fast growth rate, multipurpose applications, and high ecological values (Wang et al., 2013). Growth rate of Moso bamboo is markedly higher than those of other trees. The average shoot elongation and biomass accumulation rate have been reported to be $17 \mathrm{~cm} / \mathrm{d}$ and $96 \mathrm{~g} / \mathrm{d}$, respectively, and it typically reaches a mature state in less than two months with an average height of $15 \mathrm{~m}(\mathrm{Xu}$ et al., 2011). In China, Moso bamboo produces biomass of $121.14 \mathrm{t} / \mathrm{hm}^{2}$ (Wu et al., 2002), which is higher than that of the other hyperaccumulator species. Metal hyper-tolerance is usually a constitutive and heritable trait (Macnair, 1993). Sedum alfredii has been found to grow on $\mathrm{Pb} / \mathrm{Zn}$ mine tailing with shoot $\mathrm{Pb}$ concentrations up to $1182 \mathrm{mg} / \mathrm{kg}$. Like $S$. alfredii, Moso bamboo was also found to grow on the same $\mathrm{Pb} / \mathrm{Zn}$ mine tailing; therefore, it might have some special tolerance mechanism for these extraordinarily high concentrations of $\mathrm{Pb}$ (He et al., 2001; Zhang et al., 2006). However, no research has been conducted to study the effect of $\mathrm{Pb}$ on growth, tolerance, or metal accumulation in Moso bamboo.

The aim of the present study was to explore the phytoremediation potential of Moso bamboo plants for its application during remediation of $\mathrm{Pb}$-contaminated soils. The specific objectives were (1) to investigate the growth and physiological responses of Moso bamboo seedlings grown under $\mathrm{Pb}$ stress, (2) to investigate the uptake and accumulation of $\mathrm{Pb}$ in different plant tissues, and (3) to study the effect of $\mathrm{Pb}$ on ultrastructural characteristics of Moso bamboo.

\section{Materials and methods}

\subsection{Plant materials and hydroponics culture}

The experiment was conducted under greenhouse conditions at Zhejiang A \& F University, China, with the geographic coordinates $30^{\circ} 19^{\prime} \mathrm{N}, 119^{\circ} 35^{\prime} \mathrm{E}$. Seeds of the Moso bamboo were collected from ma- ture plants growing in Guilin, Guangxi Province, China. Healthy seeds of the Moso bamboo were surface-sterilized by water with $2 \mathrm{~g} / \mathrm{kg} \mathrm{KMnO}_{4}$ for $30 \mathrm{~min}$. After sterilization, seeds were washed using distilled water and sown in a substrate. On the emergence of seedlings, half-strength Yoshida nutrient solution (Shao et al., 2011) was supplied until seedlings with two leaf-pairs were established.

After two weeks, seedlings with the same size were selected and transferred to plastic pots containing $1.2 \mathrm{~L}$ of nutrient solution. The composition of the nutrient solution was as follows (in g/L): $45.7 \mathrm{NH}_{4} \mathrm{NO}_{3}$, $20.15 \mathrm{NaH}_{2} \mathrm{PO}_{4} \cdot 2 \mathrm{H}_{2} \mathrm{O}, 35.7 \mathrm{~K}_{2} \mathrm{SO}_{4}, 44.3 \mathrm{CaCl}_{2}, 162$ $\mathrm{MgSO}_{4} \cdot 7 \mathrm{H}_{2} \mathrm{O}, 3.73 \mathrm{Na}_{2}$ EDTA, $2.78 \mathrm{FeSO}_{4} \cdot 7 \mathrm{H}_{2} \mathrm{O}$, $0.65 \mathrm{MnSO}_{4} \cdot \mathrm{H}_{2} \mathrm{O}, 0.037\left(\mathrm{NH}_{4}\right)_{6} \mathrm{MO}_{7} \mathrm{O}_{24} \cdot 4 \mathrm{H}_{2} \mathrm{O}, 0.467$ $\mathrm{H}_{3} \mathrm{BO}_{3}, 0.0175 \mathrm{ZnSO}_{4} \cdot 7 \mathrm{H}_{2} \mathrm{O}, 0.0155 \mathrm{CuSO}_{4} \cdot 5 \mathrm{H}_{2} \mathrm{O}$, 5.95 citric acid (monohydrate) $\left(\mathrm{C}_{6} \mathrm{H}_{8} \mathrm{O}_{7}\right)$, and $0.025 \mathrm{~L}$ $98 \% \mathrm{H}_{2} \mathrm{SO}_{4}$. Different $\mathrm{Pb}$ treatments were applied as (1) control (CK), (2) $10 \mu \mathrm{mol} / \mathrm{L}$, (3) $25 \mu \mathrm{mol} / \mathrm{L}$, (4) $50 \mu \mathrm{mol} / \mathrm{L}$, (5) $100 \mu \mathrm{mol} / \mathrm{L}$, (6) $200 \mu \mathrm{mol} / \mathrm{L}$, and (7) $400 \mu \mathrm{mol} / \mathrm{L} \mathrm{Pb}$, and source of $\mathrm{Pb}$ was $\mathrm{Pb}\left(\mathrm{NO}_{3}\right)_{2}$. Three plants were grown in each pot and each treatment in triplicate.

\subsection{Plant harvest and elemental analysis}

The plants were harvested after $30 \mathrm{~d}$ and the elements were analyzed according to Islam et al. (2007).

\subsection{Analysis of root morphological parameters}

After careful washing of the roots of the harvested plants with distilled water to remove any contamination, the root length, diameter, surface area, volume, and tip numbers were recorded by an automatic scanning instrument (Epson Expression 1680) equipped with WinRHIZO software from Regent Instruments (Canada). Plant roots were placed in trays containing 7-10 $\mathrm{mm}$ depth of water for scanning and analysis. Special care was taken for untangling roots and to minimize overlapping. Three randomly selected plants from each replicate were selected for data collection.

\subsection{Ultrastructural study using electron microscopy}

After treatment with 0 and $400 \mu \mathrm{mol} / \mathrm{L} \mathrm{Pb}$ for $30 \mathrm{~d}$, plants were selected for the scanning electron microscopy (SEM) and transmission electron microscopy (TEM) study. Small sections $(1-3 \mathrm{~mm}$ in 
length) from the middle of the 3rd leaf were used for SEM (Philips Model XL30 ESEM) study. Leaf segments were selected for TEM study from the middle of the 3rd leaf from the top, using a JEOL 1200EX at an accelerating voltage of $60.0 \mathrm{kV}$ (Islam et al., 2007).

\subsection{Statistical analysis}

Statistical analysis was carried out using statistical package SPSS (Version 13.0). All values reported are means of at least three independent replicates. Data were tested at a significance level of $P<0.05$ by one-way analysis of variance (ANOVA) (least-significant difference (LSD)). Graphical work was carried out using Sigma Plot software v.12.5.

\section{Results}

\subsection{Seedling growth and biomass production}

In our hydroponics experiments, Moso bamboo was found to be tolerant to excessive amounts of $\mathrm{Pb}$ in nutrient solutions. After treatment with various levels of $\mathrm{Pb}$ for $30 \mathrm{~d}$, the plants were healthy and had fully expanded lamina with green coloration at all $\mathrm{Pb}$ treatments; no toxic symptoms were observed (Fig. 1). Even the plants exposed to the $400 \mu \mathrm{mol} / \mathrm{L} \mathrm{Pb}$ survived and no visual $\mathrm{Pb}$ toxicity symptoms such as necrosis and chlorosis were observed in these plants. For the biomass, the dry weight did not decline with the increase of $\mathrm{Pb}$ dosage (Fig. 2). At $400 \mu \mathrm{mol} / \mathrm{L} \mathrm{Pb}$ treatment, root and leaf dry weights declined significantly $(P<0.05)$; however, even at the highest $\mathrm{Pb}$ treatment, no significant difference could be traced for the dry weight of stem compared with CK.

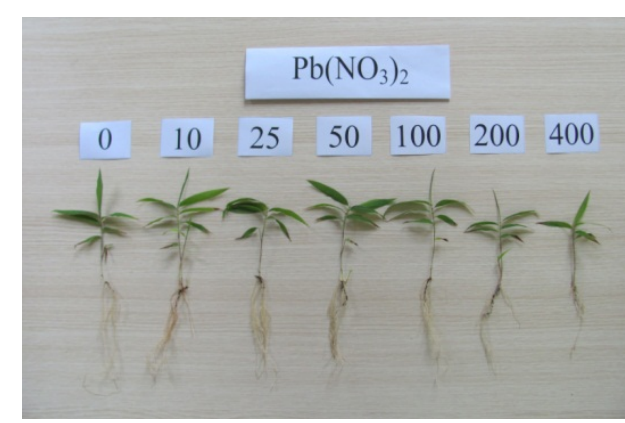

Fig. 1 Effect of $\mathrm{Pb}$ on the growth of Moso bamboo seedlings at the time of harvest

Plants were treated with various levels $(0,10,25,50,100$, 200 , and $400 \mu \mathrm{mol} / \mathrm{L}$ ) of $\mathrm{Pb}$ for $30 \mathrm{~d}$

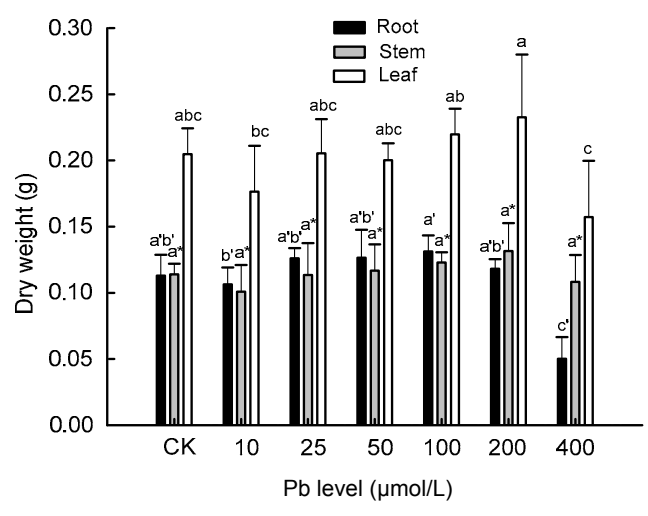

Fig. 2 Effects of different $\mathrm{Pb}$ treatments on dry biomass of Moso bamboo

Error bars are standard deviations $(n=3)$. Different letters indicate significant differences $(P<0.05)$ between the treatment and control $(\mathrm{CK})$

\subsection{Effects of $\mathrm{Pb}$ on root morphology}

Application of various $\mathrm{Pb}$ treatments caused significant changes in root morphological parameters; however, effects were more pronounced at the highest treatment (i.e., $400 \mu \mathrm{mol} / \mathrm{L} \mathrm{Pb}$ ) (Fig. 3). Fig. 3 shows that after application of $\mathrm{Pb}$ up to $200 \mu \mathrm{mol} / \mathrm{L}$, total root length, root surface, root volume, or number of tips did not decrease much and even values of all four parameters were higher at 25,50 , and $100 \mu \mathrm{mol} / \mathrm{L} \mathrm{Pb}$ compared with CK. However, the values of root length and number of tips did show a sharp decline at the $400 \mu \mathrm{mol} / \mathrm{L} \mathrm{Pb}$ treatment, where total root length, surface, volume, and number of tips decreased $61 \%, 37 \%, 40 \%$, and $57 \%$, respectively, compared with CK.

\subsection{Absorption, accumulation, and translocation of $\mathbf{P b}$}

After treatment with different $\mathrm{Pb}$ levels for $30 \mathrm{~d}$, $\mathrm{Pb}$ concentrations increased significantly in the roots and stems in line with increasing $\mathrm{Pb}$ concentrations in the culture solution (Table 1). After treatment with different $\mathrm{Pb}$ levels, $\mathrm{Pb}$ concentrations were highest in roots, followed by stems, and were lowest in leaves. At the $400 \mu \mathrm{mol} / \mathrm{L}$ treatment level, the concentrations of $\mathrm{Pb}$ were at the maximum of 4283 and $482 \mathrm{mg} / \mathrm{kg}$ in roots and stems, respectively. The transfer factor (TF) and bioaccumulation factor (BCF) tended to be decreased across all the $\mathrm{Pb}$ treatments. The TF values ranged from $0.07(400 \mu \mathrm{mol} / \mathrm{L} \mathrm{Pb})$ to $0.37(25 \mu \mathrm{mol} / \mathrm{L}$ $\mathrm{Pb})$, while $\mathrm{BCF}$ values ranged from $10.97(400 \mu \mathrm{mol} / \mathrm{L}$ 

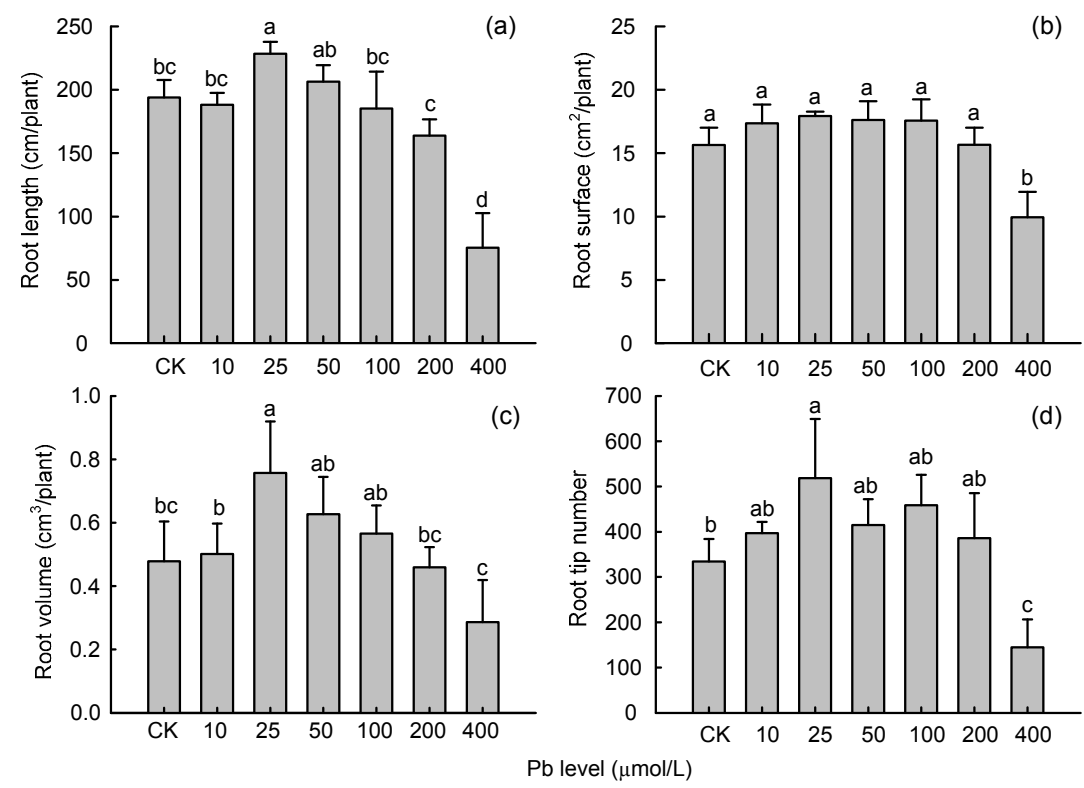

(b) Fig. 3 Total root length (a), surface area (b), root volume (c), and number of tips (d) of Moso bamboo showed different responses to different $\mathrm{Pb}$ treatments for $\mathbf{3 0} \mathrm{d}$

Error bars are standard deviations $(n=3)$. Different letters indicate significant differences $(P<0.05)$ between

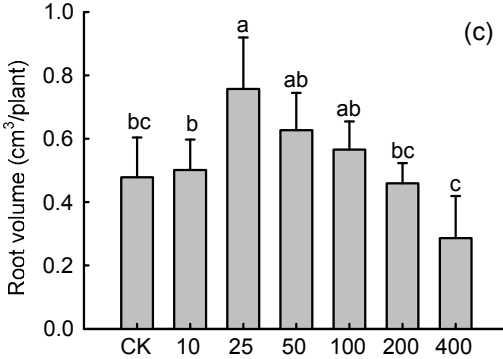
the treatment and control $(\mathrm{CK})$

$\mathrm{Pb}$ level $(\mu \mathrm{mol} / \mathrm{L})$

Table $1 \mathrm{~Pb}$ concentrations in plant tissues (roots, stems and leaves) of Moso bamboo as affected by $\mathrm{Pb}$ treatments

\begin{tabular}{|c|c|c|c|c|c|}
\hline \multirow{2}{*}{$\begin{array}{c}\mathrm{Pb} \text { treatment } \\
(\mu \mathrm{mol} / \mathrm{L})\end{array}$} & \multicolumn{3}{|c|}{$\mathrm{Pb}$ concentration $(\mathrm{mg} / \mathrm{kg})$} & \multirow{2}{*}{$\mathrm{TF}$} & \multirow{2}{*}{$\mathrm{BCF}$} \\
\hline & Root & Stem & Leaf & & \\
\hline CK & $0.6 \pm 0.5 b$ & $0.1 \pm 0.7 \mathrm{~d}$ & $0.2 \pm 0.6 \mathrm{f}$ & & \\
\hline 10 & $146 \pm 30 b$ & $56 \pm 14 \mathrm{~cd}$ & $49 \pm 9 \mathrm{e}$ & 0.36 & 37.64 \\
\hline 25 & $233 \pm 58 b$ & $94 \pm 18 \mathrm{~cd}$ & $84 \pm 3 d$ & 0.37 & 24.95 \\
\hline 50 & $331 \pm 43 b$ & $141 \pm 4 \mathrm{~cd}$ & $105 \pm 8 \mathrm{~cd}$ & 0.36 & 17.27 \\
\hline 100 & $544 \pm 103 b$ & $210 \pm 22 b c$ & $127 \pm 14 b c$ & 0.29 & 12.82 \\
\hline 200 & $1221 \pm 200 b$ & $351 \pm 56 a b$ & $165 \pm 34 a$ & 0.19 & 11.50 \\
\hline 400 & $4283 \pm 994 a$ & $482 \pm 166 \mathrm{a}$ & $149 \pm 17 \mathrm{ab}$ & 0.07 & 10.97 \\
\hline
\end{tabular}

Values of transfer factor (TF) and bioaccumulation factor (BCF) are shown: $\mathrm{TF}=C_{\mathrm{S}} / C_{\mathrm{R}}, \mathrm{BCF}=C_{\mathrm{p}} / C_{\mathrm{m}}$, where $C_{\mathrm{S}}, C_{\mathrm{R}}, C_{\mathrm{p}}$, and $C_{\mathrm{m}}$ are $\mathrm{Pb}$ concentrations in the shoot, root, plant, and medium, respectively. Different letters in the same column indicate significant differences $(P<0.05)$ among treatments and control $(\mathrm{CK})$

$\mathrm{Pb})$ to $37.64(10 \mu \mathrm{mol} / \mathrm{L} \mathrm{Pb})$. These high $\mathrm{BCF}$ values could be attributed to the high levels of metal accumulated in roots, being several fold higher than the levels in shoots. It is noteworthy that all the TF values were less than 1 , whereas all $\mathrm{BCF}$ values were more than 10. It is clear from the results that the TF and $\mathrm{BCF}$ decreased with increasing $\mathrm{Pb}$ concentrations.

\subsection{Scanning electron microscopy}

SEM shows that after treating with $\mathrm{Pb}$ the surface of the hair became reduced and was smaller slightly than that of $\mathrm{CK}$, and the stomata also diminished (Figs. 4a-4d). Abundant inclusions were observed in roots (Figs. 4e-4h), but very few were observed in stems (Figs. 4i-4l) after treatment with $\mathrm{Pb}$. The protective layer on stem surface disappeared apparently and the numbers of leaf hair reduced significantly as compared with CK.

\subsection{Transmission electron microscopy}

Transmission electron micrographs of the Moso bamboo cells of root, stem, and leaf are shown in Fig. 5. In controls (Figs. 5a, 5c, 5e, 5g, 5i, and 5k), the cells of root, stem, and leaf showed the normal performance and no toxicity symptoms were observed. Their cells were filled with cytoplasm with different organelles. Their structure was intact and the cell wall smooth. The oblong chloroplasts with regular arrangement of thylakoid membranes of the grana and starch grains and few plastoglobuli can be observed in both leaf and stem cells. Small vacuoles, a large nucleus and nucleolus, endoplasmic reticulum, and numerous plasmodesmata were visible in root cells of control plants. After treatment with $400 \mu \mathrm{mol} / \mathrm{L} \mathrm{Pb}$, the symptoms of $\mathrm{Pb}$ toxicity were observed in these cells. The cell walls in leaf, stem, and root cells were swollen and their structure was distorted 

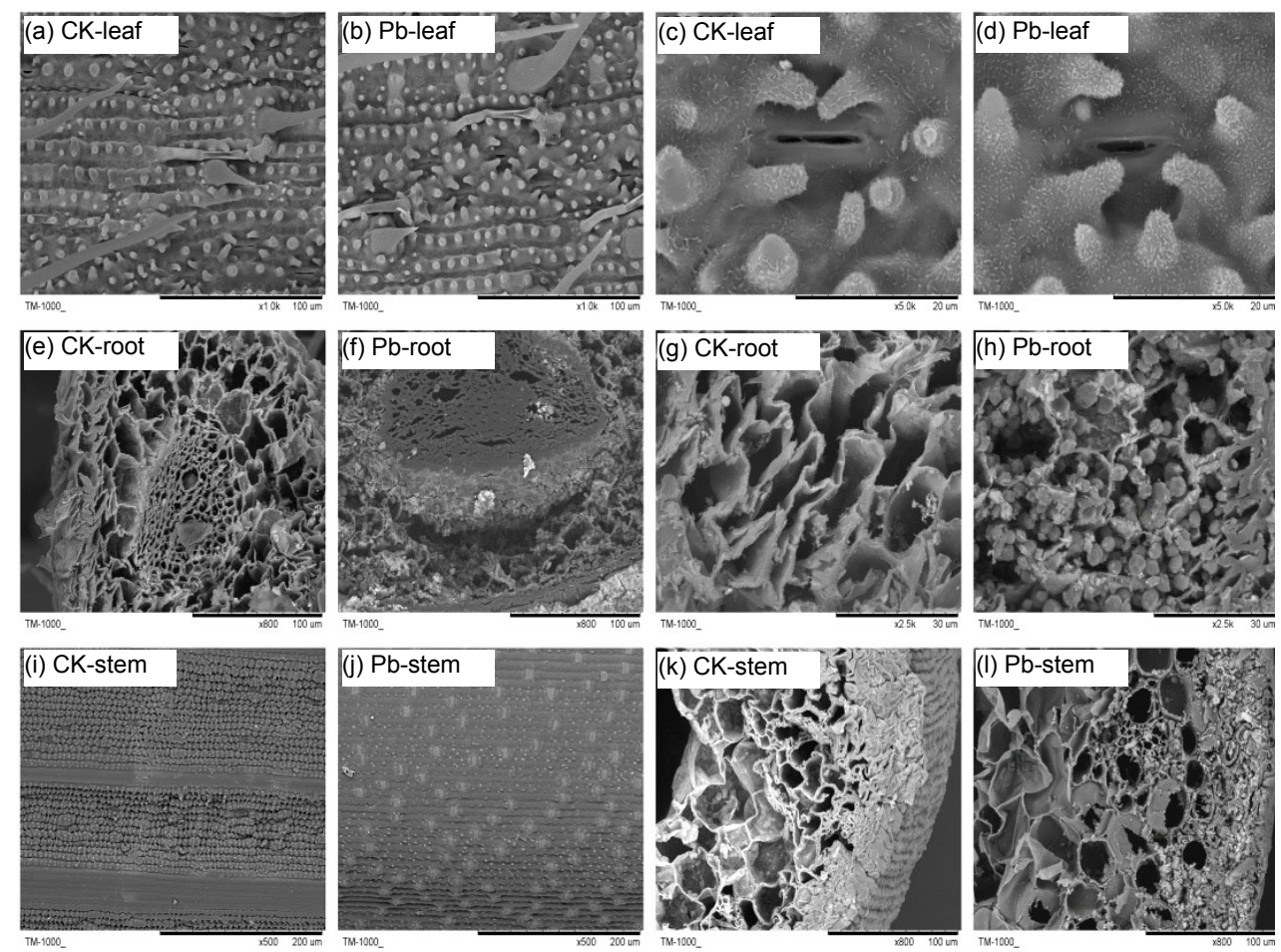

Fig. 4 Scanning electron micrographs of cross-sections of Moso bamboo leaf (a-d), root (e-h), and stem (i-l) treated with 0 and $400 \mu \mathrm{mol} / \mathrm{L} \mathrm{Pb}$ for $30 \mathrm{~d}$

Control (CK; $0 \mu \mathrm{mol} / \mathrm{L} \mathrm{Pb})$ : a, c, e, g, I, and k; $400 \mu \mathrm{mol} / \mathrm{L} \mathrm{Pb}$ treated: b, d, f, h, j, and 1
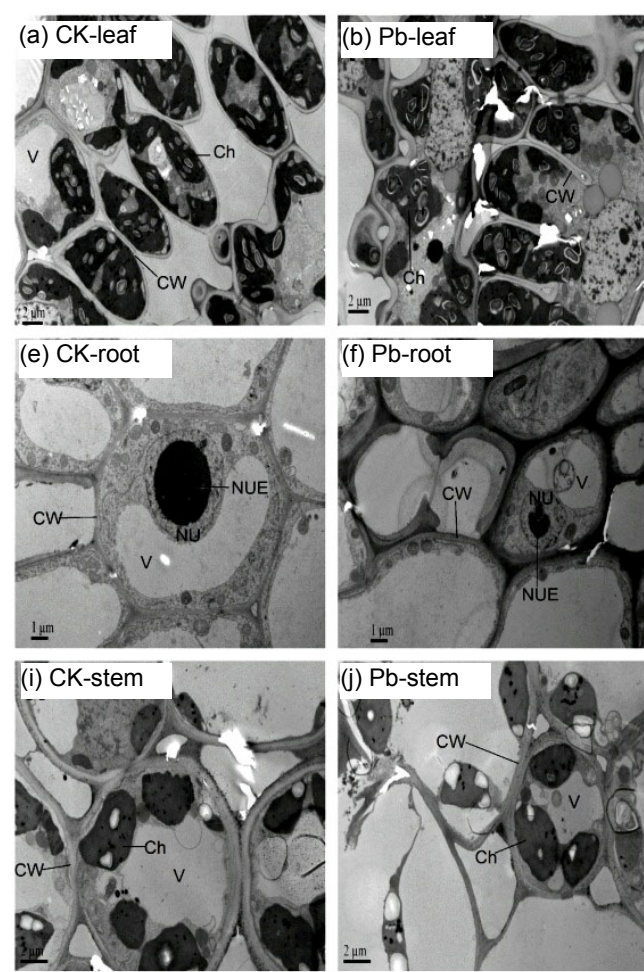
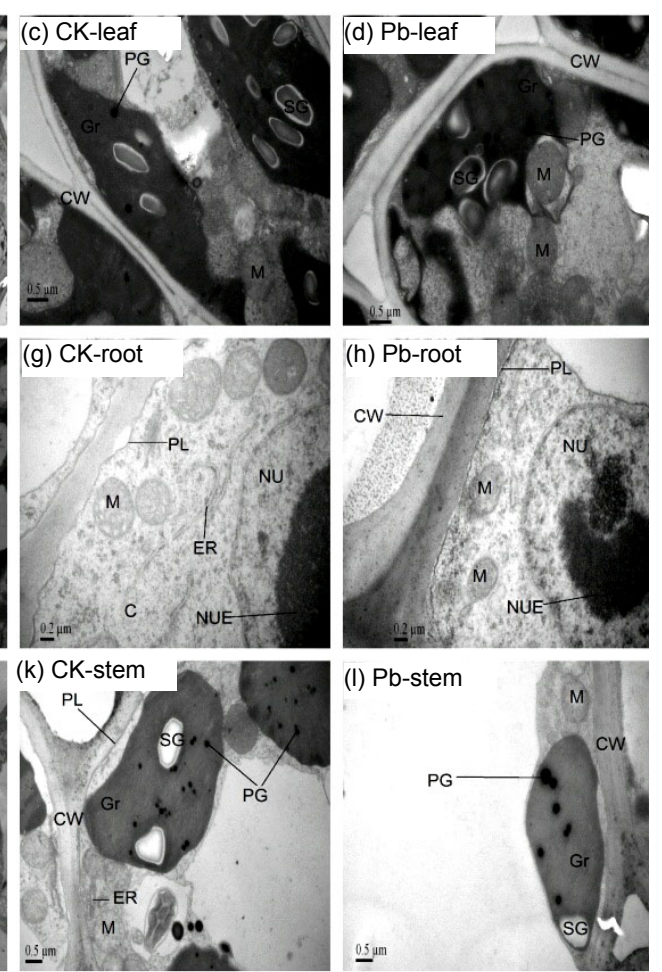

Fig. 5 Transmission electron micrographs of the leaf $(a-d)$, root $(e-h)$, and stem (i-l)

Ultrathin sections of the Moso bamboo exposed to 0 and $400 \mu \mathrm{mol} / \mathrm{L} \mathrm{Pb}$ for $30 \mathrm{~d}$. Control $(\mathrm{CK} ; 0 \mu \mathrm{mol} / \mathrm{L} \mathrm{Pb}): \mathrm{a}, \mathrm{c}, \mathrm{e}, \mathrm{g}$, i, and k. $400 \mu \mathrm{mol} / \mathrm{L} \mathrm{Pb}$ treated: b, d, f, h, j, and l. Labels: Ch, chloroplast; CW, cell wall; Gr, granum; PG, plastoglobule; M, mitochondrion; PL, plasmalemma; SG, starch grain; NU, nucleus; NUE, nucleolus; V, vacuole; C, cytoplasm; ER, endoplasmic reticulum 
(Figs. 5b, 5d, 5f, 5h, 5j, and 5l). In leaf cells, abnormally shaped chloroplasts and dissolved thylakoid membranes were observed; however, the shape of mitochondria changed slightly. There were sparse cytoplasm, decreased numbers of mitochondria, large vacuoles, and shrunken nuclei with reduced nucleoli in the meristematic cells of root.

\section{Discussion}

It is known that $\mathrm{Pb}$ toxicity is one of the most dangerous environmental pollutants, which inhibits plant growth and development (Cobbett, 2000). Toxicity symptoms include changes in various physiological responses to high concentrations of $\mathrm{Pb}$. These changes include enzyme activity inhibition, mineral nutrition distortion, and membrane permeability imbalance (Sharma and Dubey, 2005).

The superiority of Moso bamboo to maintain its growth potential and to tolerate $\mathrm{Pb}$ could, at least partly, be due to selective absorption of essential nutrients from contaminated substrates to maintain appropriate nutrition of their photosynthetic organs (Zaier et al., 2010). Observations on the growth of Moso bamboo and assessment of the root, stem, and leaf revealed that $100 \mu \mathrm{mol} / \mathrm{L}$ of $\mathrm{Pb}$ does not affect dry weights, which suggests that Moso bamboo is able to tolerate low doses of $\mathrm{Pb}$. A lesser effect of $\mathrm{Pb}$ was observed on stem growth compared with root at high levels of $\mathrm{Pb}(400 \mu \mathrm{mol} / \mathrm{L})$, because the first point of contact for this toxic metal is the root (Nada et al., 2007). In a study on willow, when $\mathrm{Pb}$ treatments were above the $169 \mu \mathrm{mol} / \mathrm{L}$, plants showed stunted growth, chlorosis, and serious root biomass reduction. However, Moso bamboo grew healthy and had fully expanded lamina with green coloration when plants were grown at the $200 \mu \mathrm{mol} / \mathrm{L} \mathrm{Pb}$, and no toxic symptoms were observed. In corn seedlings and the non-mined ecotype of Elsholtzia argyi, owing to an increase in the cell wall polysaccharides resulting from $\mathrm{Pb}$ exposure, an obvious increase in dry weight of plant organs was reported (Islam et al., 2007). In the present study, the increase in the dry weight of Moso bamboo noted at $200 \mu \mathrm{mol} / \mathrm{L} \mathrm{Pb}$ might also be due to the increased synthesis of cell wall polysaccharides in the nutrient solution. It has been reported that when the growth and physiological parameters fall to $50 \%$ of CK, plant growth is seriously inhibited (Li et al., 2014). In the present study, the dry weight of Moso bamboo was greater than that of CK in all treatments except for 10 and $400 \mu \mathrm{mol} / \mathrm{L} \mathrm{Pb}$; on the other hand, dry weights only decreased $27 \%$ compared with $\mathrm{CK}$ even at $400 \mu \mathrm{mol} / \mathrm{L} \mathrm{Pb}$, revealing that Moso bamboo is more suitable for remediation of highly $\mathrm{Pb}$ contaminated soil.

Root systems are especially susceptible to heavy metal stress, so the root parameters of plants can be used as important indices (Fan et al., 2011). The results of the present study showed that better root growth and increased $\mathrm{Pb}$ uptake by Moso bamboo are attributed to the maintenance of their root activity under $\mathrm{Pb}$ stress. Also our results revealed that roots of the Moso bamboo plants have great potential to tolerate and absorb $\mathrm{Pb}$ from the growth medium. It was reported that Cucumis sativus could retain greater amounts of metals in the roots on account of its root morphology (An et al., 2004); the greater surface area of these roots is known to contribute more to the absorption of heavy metals and nutrient (Li et al., 2014). Aboveground biomass is also an important indicator of the phytoremediation potential. $\mathrm{Pb}$ concentrations in stem tissues of Moso bamboo were $482.25 \mathrm{mg} / \mathrm{kg}$ at the $400 \mu \mathrm{mol} / \mathrm{L} \mathrm{Pb}$. Although the concentration did not reach the standard of hyperaccumulators, considering the greater biomass and the leaves occupying only $4 \%$ of all biomass of Moso bamboo (Chen et al., 1998), it is still quite valuable for phytoremediation purposes.

Roots are the first organ to come into contact with $\mathrm{Pb}$, and provide the primary route for the penetration of metal ions (Piechalak et al., 2002). It has been well documented that most species roots always accumulated much higher $\mathrm{Pb}$ than shoots (LópezMillán et al., 2009). Enrichment occurs when heavy metal is taken up by a plant, resulting in an accumulation in the plant. $\mathrm{BCF}$ values higher than 1 are indicative of potential hyperaccumulator species (Audet and Charest, 2007). All the BCF were more than 10 and these high $\mathrm{BCF}$ values could be attributed mainly to the metal accumulated in the roots several-fold higher than that in the shoots. This high retention corroborates the role of roots, minimizes transport to the shoots, and represents a tolerance mechanism important for phytostabilization processes (Pulford and Watson, 2003). Plants exhibiting TF and 
particularly BCF values greater than 1 are suitable for phytoremediation. Although Moso bamboo does not reach this standard, it could show normal growth and biomass did not decrease at $\mathrm{Pb}<400 \mu \mathrm{mol} / \mathrm{L}$. Given that $\mathrm{TF}$ reaches 0.29 at $100 \mu \mathrm{mol} / \mathrm{L} \mathrm{Pb}$, and considering the high biomass values and advantages in postharvest disposal of Moso bamboo, it is suggested that it has great potential as excellent phytoremediation material.

Hyperaccumulators, which retain most of the heavy metal taken up from the soil in the root and detoxify them by chelation in the cytoplasm or storing them in vacuoles, rapidly and efficiently translocate these elements to the shoot via the xylem (Rascio and Navari-Izzo, 2011). There were abundant inclusions observed in roots and very few in stems after treatment with $\mathrm{Pb}$. Metal tolerance was often accompanied by a variety of intracellular changes (Hall, 2002; Sinha et al., 2007). Moso bamboo cell wall, chloroplasts, thylakoid membranes, mitochondria, cytoplasm, vacuoles, and nucleus had a variety of changes, which might reflect metal tolerance capacity of these plants.

$\mathrm{Pb}$ toxicity is largely dependent upon absorption, transport, and cellular localization of $\mathrm{Pb}$ (Singh et al., 1997). The roots of Moso bamboo had the highest $\mathrm{Pb}$ concentrations compared with other tissues. In TEM studies, the root of Moso bamboo was found to contain small aggregates deposited in the cell wall fractions. This deposition pattern partly explains why roots of Moso bamboo were not able to transfer $\mathrm{Pb}$ to aerial parts very well, which limits the apoplastic transport of $\mathrm{Pb}$ (Rudakova et al., 1988). A probable explanation was that in the cell wall, $\mathrm{Pb}$ binds to ion exchangeable sites and with further extracellular precipitation as $\mathrm{Pb}$ carbonates (Sharma and Dubey, 2005). Short exposure to $\mathrm{Pb}$ may lead to poor translocation of $\mathrm{Pb}$ from roots to shoots (Dos Santos Utmazian et al., 2007).

To date, no work has been reported regarding the $\mathrm{Pb}$ accumulation potential of Moso bamboo plants. It grows abundantly in China, growing round the year with a high rate of primary production (58.7 $\mathrm{t}$ dry weight/ha) (Chen et al., 1998), which shows that Moso bamboo might be a good phytoremediation species considering its large biomass compared with other $\mathrm{Pb}$ accumulators. The results of these studies open a new perspective for the selection of plant species for phytoremediation purposes.

\section{Compliance with ethics guidelines}

Dan LIU, Song LI, Ejazul ISLAM, Jun-ren CHEN, Jia-sen WU, Zheng-qian YE, Dan-li PENG, Wen-bo YAN, and Kou-ping LU declare that they have no conflict of interest.

This article does not contain any studies with human or animal subjects performed by any of the authors.

\section{References}

An, Y.J., Kim, Y.M., Kwon, T.I., et al., 2004. Combined effect of copper, cadmium, and lead upon Cucumis sativus growth and bioaccumulation. Sci. Total Environ., 326(1-3): 85-93. [doi:10.1016/j.scitotenv.2004.01.002]

Audet, P., Charest, C., 2007. Heavy metal phytoremediation from a meta-analytical perspective. Environ. Pollut., 147(1):231-237. [doi:10.1016/j.envpol.2006.08.011]

Chen, H., Hong, W., Wei, L., et al., 1998. Study on biomass and productivity of Phyllostachys heterocycala cv. Pubescens forest in the north of Fujian. Sci. Silvae Sin., 34(S1):60-64 (in Chinese).

Chen, X.G., Zhang, X.Q., Zhang, Y.P., et al., 2009. Changes of carbon stocks in bamboo stands in China during 100 years. Forest Ecol. Manag., 258(7):1489-1496. [doi:10.1016/ j.foreco.2009.06.051]

Cho-Ruk, K., Kurukote, J., Supprung, P., 2006. Perennial plants in the phytoremediation of lead-contaminated soils. Biotechnology, 5(1):1-4. [doi:10.3923/biotech.2006.1.4]

Cobbett, C.S., 2000. Phytochelatins and their roles in heavy metal detoxification. Plant Physiol., 123(3):825-832. [doi:10.1104/pp.123.3.825]

Dos Santos Utmazian, M.N., Wieshammer, G., Vega, R., et al., 2007. Hydroponic screening for metal resistance and accumulation of cadmium and zinc in twenty clones of willows and poplars. Environ. Pollut., 148(1):155-165. [doi:10.1016/j.envpol.2006.10.045]

Epelde, L., Hernández-Allica, J., Becerril, J.M., et al., 2008. Effects of chelates on plants and soil microbial community: comparison of EDTA and EDDS for lead phytoextraction. Sci. Total Environ., 401(1-3):21-28. [doi:10.1016/j.scitotenv.2008.03.024]

Fan, K.C., Hsi, H.C., Chen, C.W., et al., 2011. Cadmium accumulation and tolerance of mahogany (Swietenia macrophylla) seedlings for phytoextraction applications. J. Environ. Manag., 92(10):2818-2822. [doi:10.1016/ j.jenvman.2011.06.032]

Hall, J.L., 2002. Cellular mechanisms for heavy metal detoxification and tolerance. J. Exp. Bot., 53(366):1-11. [doi:10.1093/jexbot/53.366.1]

He, B., Yang, X.E., Ni, W.Z., et al., 2001. Sedum alfredii: a new lead-accumulating ecotype. Acta Bot. Sin., 44(11): 1365-1370 (in Chinese).

Islam, E., Yang, X.E., Li, T.Q., et al., 2007. Effect of Pb toxicity on root morphology, physiology and ultrastructure in the two ecotypes of Elsholtzia argyi. J. Hazard. Mater., 147(3):806-816. [doi:10.1016/j.jhazmat.2007.01.117]

Krämer, U., 2010. Metal hyperaccumulation in plants. Annu. Rev. Plant Biol., 61(1):517-534. [doi:10.1146/annurevarplant-042809-112156]

Li, S.L., Wang, F.P., Ru, M., et al., 2014. Cadmium tolerance and accumulation of Elsholtzia argyi origining from a 
zinc/lead mining site - a hydroponics experiment. Int. J. Phytoremediat., 16(12):1257-1267. [doi:10.1080/15226514. 2013.828010]

López-Millán, A.F., Sagardoy, R., Solanas, M., et al., 2009. Cadmium toxicity in tomato (Lycopersicon esculentum) plants grown in hydroponics. Environ. Exp. Bot., 65(2-3): 376-385. [doi:10.1016/j.envexpbot.2008.11.010]

Macnair, M.R., 1993. The genetics of metal tolerance in vascular plants. New Phytol., 124(4):541-559. [doi:10.1111/ j.1469-8137.1993.tb03846.x]

Nada, E., Ferjani, B.A., Ali, R., et al., 2007. Cadmium-induced growth inhibition and alteration of biochemical parameters in almond seedlings grown in solution culture. Acta Physiol. Plant., 29(1):57-62. [doi:10.1007/s11738-0060009-y]

Patra, M., Bhowmik, N., Bandopadhyay, B., et al., 2004. Comparison of mercury, lead and arsenic with respect to genotoxic effects on plant systems and the development of genetic tolerance. Environ. Exp. Bot., 52(3):199-223. [doi:10.1016/j.envexpbot.2004.02.009]

Piechalak, A., Tomaszewska, B., Baralkiewicz, D., et al., 2002. Accumulation and detoxification of lead ions in legumes. Phytochemistry, 60(2):153-162. [doi:10.1016/S0031-9422 (02)00067-5]

Pulford, I., Watson, C., 2003. Phytoremediation of heavy metalcontaminated land by trees - a review. Environ. Int., 29(4):529-540. [doi:10.1016/S0160-4120(02)00152-6]

Rascio, N., Navari-Izzo, F., 2011. Heavy metal hyperaccumulating plants: How and why do they do it? And what makes them so interesting? Plant Sci., 180(2):169-181. [doi:10.1016/j.plantsci.2010.08.016]

Rudakova, E.V., Karakis, K.D., Sidorshina, E.T., 1988. The role of plant cell walls in uptake and accumulation of metal ions. Fiziol. Biochim. Kult. Rast., 20(1):3-12.

Ruley, A.T., Sharma, N.C., Sahi, S.V., et al., 2006. Effects of lead and chelators on growth, photosynthetic activity and $\mathrm{Pb}$ uptake in Sesbania drummondii grown in soil. Environ Pollut., 144(1):11-18. [doi:10.1016/j.envpol.2006.01.016]

Shao, J.F., Gui, R.Y., Ji, H.B., et al., 2011. A preliminary study on establishment of hydroponic culture system for Phyllostachys pubescens seedlings. J. Zhejiang A \& F Univ., 28(1):86-94 (in Chinese).

Sharma, P., Dubey, R.S., 2005. Lead toxicity in plants. Braz. J. Plant Physiol., 17(1):35-52. [doi:10.1590/S1677-04202 005000100004]

Singh, R.P., Tripathi, R.D., Sinha, S., et al., 1997. Response of higher plants to lead contaminated environment. Chemosphere, 34(11):2467-2493. [doi:10.1016/S0045-6535 (97)00087-8]

Sinha, S., Gupta, A.K., Bhatt, K., 2007. Uptake and translocation of metals in fenugreek grown on soil amended with tannery sludge: involvement of antioxidants. Ecotoxicol. Environ. Saf., 67(2):267-277. [doi:10.1016/j.ecoenv.2006. 07.005]

Tandy, S., Schulin, R., Nowack, B., 2006. The influence of EDDS on the uptake of heavy metals in hydroponically grown sunflowers. Chemosphere, 62(9):1454-1463. [doi:10. 1016/j.chemosphere.2005.06.005]

Verbruggen, N., Hermans, C., Schat, H., 2009. Molecular mechanisms of metal hyperaccumulation in plants. New Phytol., 181(4):759-776. [doi:10.1111/j.1469-8137.2008. 02748.x]

Wang, B., Wei, W.J., Liu, C.J., et al., 2013. Biomass and carbon stock in Moso bamboo forests in subtropical China: characteristics and implications. J. Trop. For. Sci., 25(1):137-148 (in Malay).

Wu, J.S., Yu, Y.W., Zhu, Z., et al., 2002. Studies on the biomass of different forests in Huzhou city. J. Jiangsu Forest. Sci. Technol., 29(4):22-24 (in Chinese).

Xi, X.Y., Liu, M.Y., Huang, Y., et al., 2010. Response of flue-cured tobacco plants to different concentration of lead or cadmium. 2010 4th International Conference on Bioinformatics and Biomedical Engineering (iCBBE). IEEE, p.1-4. [doi:10.1109/ICBBE.2010.5517715]

Xu, Y., Wong, M., Yang, J., et al., 2011. Dynamics of carbon accumulation during the fast growth period of bamboo plant. Bot. Rev., 77(3):287-295. [doi:10.1007/s12229011-9070-3]

Zaier, H., Ghnaya, T., Lakhdar, A., et al., 2010. Comparative study of Pb-phytoextraction potential in Sesuvium portulacastrum and Brassica juncea: tolerance and accumulation. J. Hazard. Mater., 183(1-3):609-615. [doi:10. 1016/j.jhazmat.2010.07.068]

Zhang, L., Ye, Z.Q., Li, T.Q., et al., 2006. Studies on soil microbial activity in areas contaminated by tailings from $\mathrm{Pb}, \mathrm{Zn}$ mine. J. Soil Water Conserv., 20(3):136-140 (in Chinese).

\section{中文概要}

\section{题 目: 植物修复的应用: 毛竹苗对铅的积累与耐性研究}

目 的: 探索毛竹在修复铅污染土壤的植物修复潜力。

创新点: 使用了毛竹作为一种全新的植物修复材料进行研 究。得到了毛竹幼苗在铅胁迫下的生长与生理反 应情况, 不同植物组织对铅的吸收与积累情况, 铅胁迫下毛竹幼苗表层与细胞超微结构的特征。

方 法: 根系形态分析（图 3) 、植物重金属含量分析 （表 1)、扫描电镜分析（图 4) 和透射电镜分 析 (图 5)。

结 论: 各组织部位铅浓度的值揭示了, 毛竹是一个很好 的固定铅污染土壤的植物材料; 但是由于毛竹茎 的高生物量, 也可以作为铅污染土壤的植物修复 材料。在 0 200 $\mu \mathrm{mol} / \mathrm{L}$ 铅处理下, 毛竹的生物量 与根系形态没有显著性差异, 生长正常未出现中 毒症状。通过扫描电镜观察铅胁迫导致叶片的气 孔减少, 根与茎内含物增多。通过透射电镜观察 高浓度的铅胁迫导致部分细胞内部叶绿体变形、 内质网消失、细胞核与核仁缩小和类囊体膜消 失。尽管超微结构观察到细胞内部的损害, 但是 未出现视觉的毒性症状。毛竹铅的高耐性与茎的 高生物量, 提供了毛竹作为材料修复土壤重金属 铅更大的可能性。

关键词: 毛竹; 植物修复; 铅; 扫描电镜; 透射电镜 